\title{
The Inferior Epigastric Artery: Anatomical Study and Clinical Significance
}

\author{
Arteria Epigástrica Inferior: Estudio Anatómico y Significancia Clínica
}

\author{
Waseem Al-Talalwah
}

AL-TALALWAH, W. The inferior epigastric artery: anatomical study and clinical significance. Int. J. Morphol., 35(1):7-11, 2017.

SUMMARY: The inferior epigastric artery usually arises from the external iliac artery. It may arise from different origin. The aim of current study is to provide sufficient date of the inferior epigastric artery for clinician, radiologists, surgeons, orthopaedic surgeon, obstetricians and gynaecologists. The current study includes 171 dissected cadavers ( 92 male and 79 female) to investigate the origin and branch of the inferior epigastric artery in United Kingdom population (Caucasian) as well as in male and female. The inferior epigastric artery found to be a direct branch arising independently from the external iliac artery in $83.6 \%$. Inferior epigastric artery arises from common trunk of external iliac artery with the obturator artery or aberrant obturator artery in $15.1 \%$ or $1.3 \%$. Further, the inferior epigastric artery gives obturator and aberrant obturator branch in $3.3 \%$ and $0.3 \%$. Therefore, the retropubic connection vascularity is 20 $\%$ which is more in female than male. As the retropubic region includes a high vascular variation, a great precaution has to be considered prior to surgery such as hernia repair, internal fixation of pubic fracture and skin flap transplantation. The radiologists have to report treating physicians to decrease intra-pelvic haemorrhage due to iatrogenic lacerating obturator or its accessory artery fracture.

KEY WORDS: Inferior epigastric; Obturator; Aberrant Oburator; Accessory Obturator; Hernia; Corona Mortis; Pubic

\section{INTRODUCTION}

The inferior epigastric artery usually arises from the external iliac artery. It ascends medial to the deep inguinal ring in the subperitoneal tissue and penetrates the transversalis fascia to be flanked by the rectus abdominis and its sheath (Standring, 2005). Historically, the inferior epigastric artery was described by Beckers in 1813. Ramsay described the relation of the inferior epigastric artery with obturator artery (Bergman et al., 1988).

At the level of umbilicus, it gives several muscular branches and anastomoses with the superior epigastric branch of the internal mammary and lower intercostal arteries. It also anastomoses with the iliac circumflex iliac, lumbar and superficial epigastric arteries. Infrequently, it may arise from the femoral artery instead of external iliac artery. It also arises with obturator artery as a common trunk from the external iliac artery (Standring).

The variability in the origin and branching pattern of the inferior epigastric artery which may communicate with the internal iliac system has a high risk of internal haemorrhage in superior pubic fractures and inguinal or femoral hernial repairs. Therefore, the current study focuses on the anatomical features of inferior epigastric artery such as the origin and branching pattern to prevent iatrogenic errors. It will also help to increase the success rate of abdominal and pelvic operations in clinical field.

\section{MATERIAL AND METHOD}

The present study comprised of 171 embalmed cadavers (92 males and 79 females). These cadavers were dissected $(n=171)$ and their right and left sides were examined to study the gross anatomic characteristics of the inferior epigastric artery including its mode of origin. The age of the cadavers ranged from 37-96 years for investigation of the inferior epigastric artery origin and branches. The current study has been conducted in Centre for Anatomy and Human Identification, University of Dundee in UK. This study based on dissection and it was conducted on the 
embalmed cadavers used for undergraduate teaching. Once students had finished dissection sessions for the anterior abdominal wall, foregut and hindgut the following procedure was carried out on the cadavers. A transverse section at or above L4 or L5 vertebral level was made followed by sagittal section of the pelvis. After dividing the pelvis, the peritoneum was removed carefully. At the pubic bone, the peritoneum attached to the superior pubic ramus was released to identify the possibility of presence of obturator artery or an accessory (aberrant) obturator artery as a branch of the inferior epigastric artery. The aberrant obturator artery is an accessory artery arising from the external iliac system beside coexistence with the obturator artery itself normally arising from the internal iliac artery. Therefore, the urinary bladder was reflected away from the pubic bone to identify the obturator artery or its accessory counterpart. The retropubic space was occupied by a variable amount of fat, which was carefully removed. At the pelvic brim, the common iliac artery bifurcates into external and internal iliac arteries. The external iliac artery was inspected and its branches identified, being careful not to miss the inferior epigastric artery origin as a direct or indirect with the obturator or its accessory artery. At the level of the internal iliac artery bifurcation, the obturator artery was found to arise either on the lateral or on the dorsolateral surface of the anterior trunk. It was also found to arise from the anterior trunk below the origin of the umbilical artery. The observed data was analysed by calculating the percentages of the normal and aberrant origins of the vessels under study.

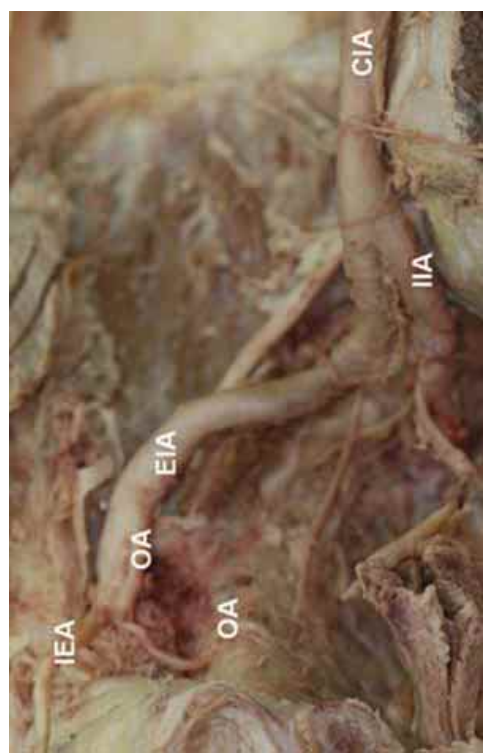

Fig. 1. The inferior epigastric artery arising from the external iliac artery. CIA. Common iliac artery; EIA. external iliac artery IIA. Internal iliac artery; IEA.; OA. obturator artery (Right. Hemipelvis - Male). Female).

\section{RESULTS}

In the present study, it investigated the origin of the inferior epigastric artery in 171 embalmed cadavers ( 92 male and 79 female). After carrying out sagittal sections of pelvis we had a total number of 342 specimens. Out of these, in 38 specimens the data regarding their dates was missing. Therefore, they were excluded from the study. Therefore, the corrected percentage has been taken as the right incidence of the variations. The inferior epigastric artery arose from the external iliac artery in $83.6 \%$ independently (Fig. 1). The inferior epigastric artery arose dependently as from common trunk of external iliac artery with the obturator artery or aberrant obturator artery in $15.1 .8 \%$ or $1.3 \%$ (Fig. 2). Further, the inferior epigastric artery found to have obturator and aberrant obturator branch in $3.3 \%$ and $0.3 \%$ of the cases (Fig. 3). Therefore, the arterial connection of the inferior epigastric artery and obturator or its accessory branch is $20 \%$.

Furthermore, the current study focussed on the arterial connection of the inferior epigastric artery and obturator or its accessory in both genders. In male, the inferior epigastric artery arose from the external iliac artery in $88.1 \%$ independently. Inferior epigastric artery arose dependently as from common trunk of external iliac artery with the obturator artery and aberrant obturator artery in $11.3 \%$ and $0.3 \%$. Further, the inferior epigastric artery found to have obturator artery in $1.9 \%$. Therefore, the incidences arterial

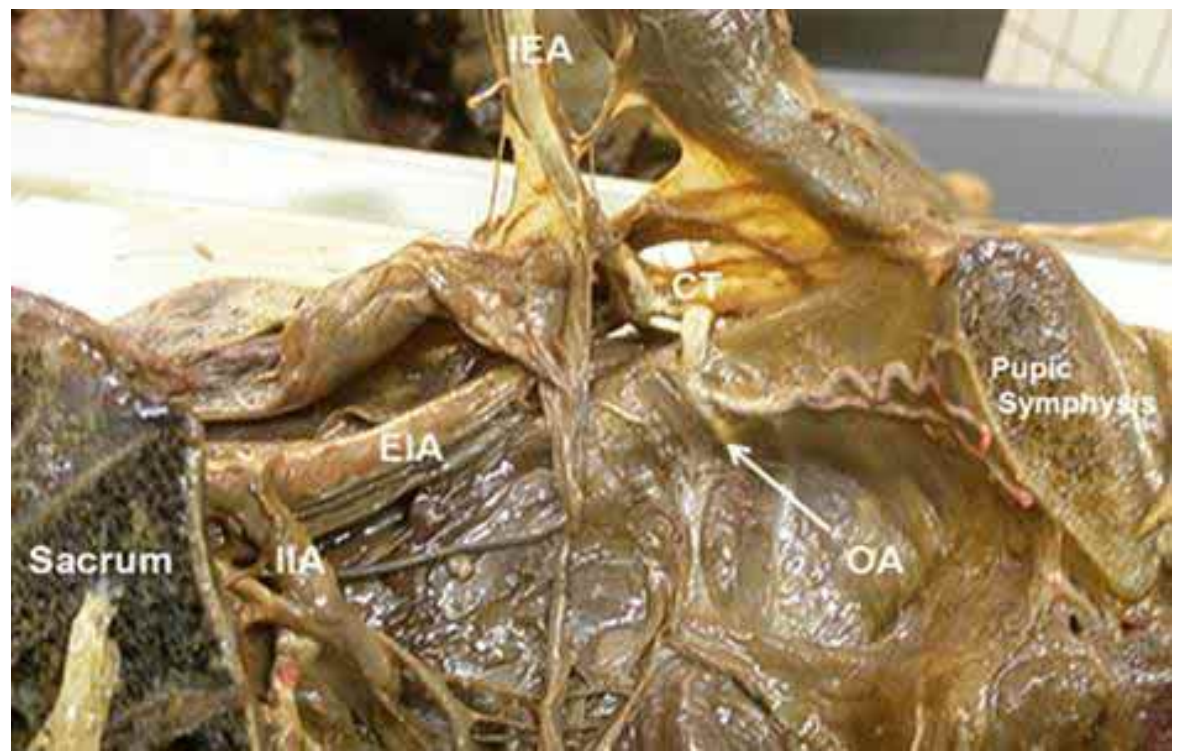

Fig. 2. The inferior epigastric artery arising from the external iliac artery indirectly from a common trunk with the obturator artery. EIA. External iliac artery IIA. Internal iliac artery; IEA. inferior epigastric artery; CT. Common trunk; OA. obturator artery (Left. Hemipelvis - 


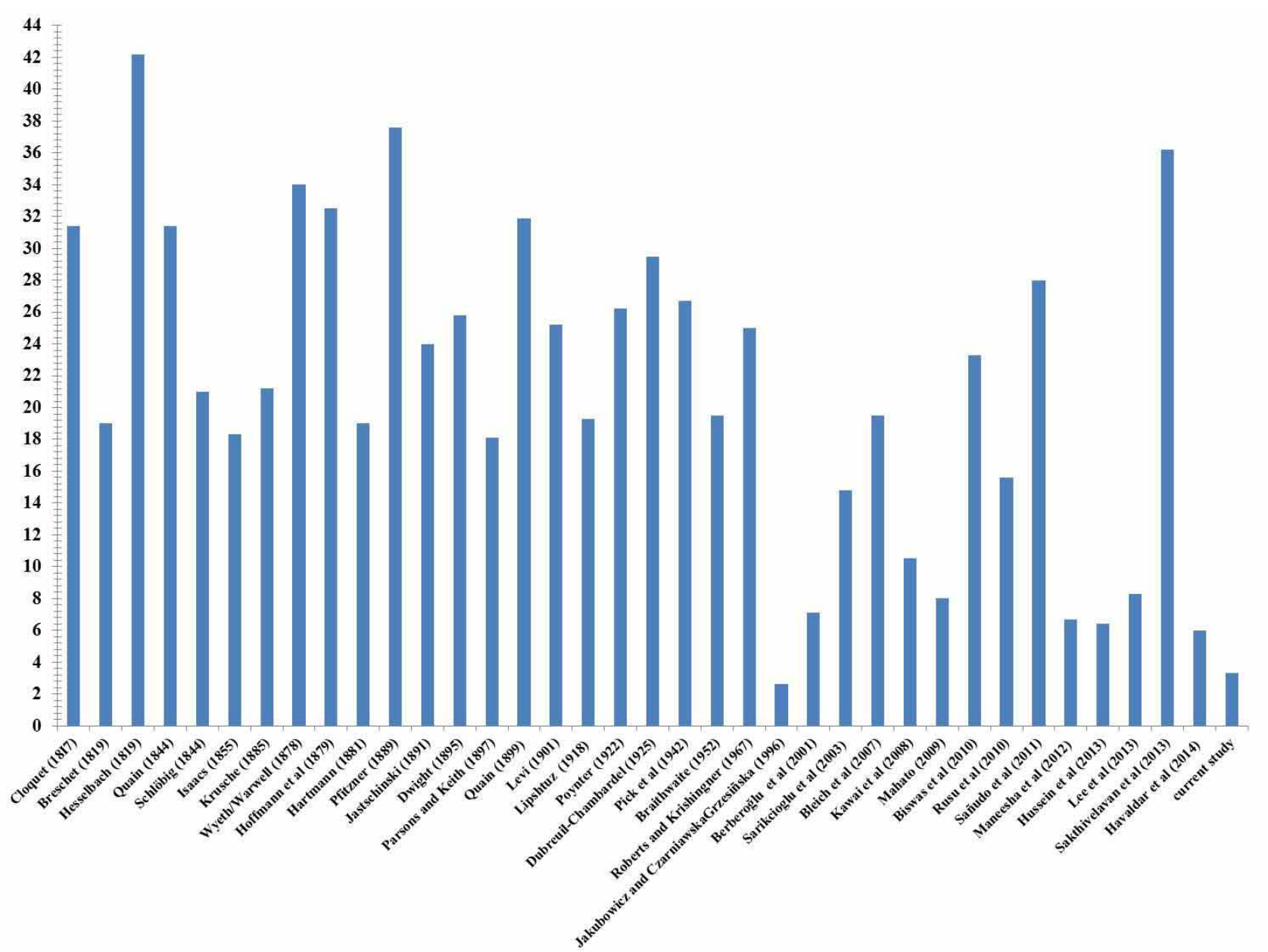

Fig. 3. The inferior epigastric artery providing the obturator artery in series and current study.

connection of the inferior epigastric artery with obturator artery or its accessory found to be $13.8 \%$. In female, the inferior epigastric artery arose from the external iliac artery in $78.5 \%$ independently. Inferior epigastric artery arose dependently as from common trunk of external iliac artery with the obturator artery and aberrant obturator artery in 19.4 $\%$ and $2.1 \%$. Further, the inferior epigastric artery found to have obturator and aberrant obturator branch in $4.3 \%$ and $0.7 \%$. Therefore, the arterial connection of the inferior epigastric artery and obturator artery or its accessory found to be $27.1 \%$.

\section{DISCUSSION}

The inferior epigastric artery frequently arises from the external iliac artery in $88 \%$ but it also arises from the femoral artery in $8 \%$ (Jakubowicz \& CzerniawskaGrzesiñska, 1996). Further, the inferior epigastric artery frequently arises indirectly from external iliac artery as from a common trunk with other arteries such as deep circumflex iliac artery, the obturator artery (Kawai et al., 2008 \& Hussein et al., 2013) or with the obturator and medial circumflex femoral arteries (Sañudo et al., 2011). The common trunk can be stemmed from the external iliac or femoral artery (Kawai et al.; Hussein et al.). In following review studies, the inferior epigastric artery was found to arise with obturator artery as from a common trunk of external iliac artery ranging between 20 to $30 \%$ (Bergman et al.). Based on different studies, the current review found the incidence of the inferior epigastric artery arising from common trunk of external iliac artery with obturator artery found to be between 10.5 to $27.3 \%$ (Kawai et al. \& Hussein et al.). In contrast, it has been estimated less than previous review studies in $4 \%$ (Jakubowicz \& Czerniawska-Grzesiñska) and $5.2 \%$ (Pai et al., 2009). In this study, it arose with the obturator artery from the common trunk of external iliac artery in $15.1 \%$ in Caucasian.

Further, the inferior epigastric artery was found to arise from the obturator artery in $4 \%$ (Kawai et al.). On the 
other hand, the obturator artery was found to arise from the inferior epigastric artery as reported in literature review done by Bergman et al. study and found to be ranging from $19 \%$ to $42 \%$. The current study updates the Bergman et al. review study in which the incidence of the inferior epigastric artery giving obturator artery found to be between $2.6 \%$ and $44 \%$ based on latest research studies (Roberts and Krishingner, 1967; Jakubowicz \& Czerniawska-Grzesiñska; Berberoglu et al., 2001; Sarikcioglu et al., 2003; Bleich et al., 2007; Kawai et al.; Mahato, 2009; Biswas et al., 2010; Rusu et al., 2010; Sañudo et al.; Maneesha et al., 2012; Hussein et al.; Lee et al., 2013; Sakthivelavan et al., 2013 \& Havaldar et al., 2014). In current study, the inferior epigastric artery gives obturator artery in $3.3 \%$ which is more in female than in male.

Furthermore, the current study updates the review study done by Bergman et al. in which the incidence of an aberrant obturator artery found to be between $1 \%$ and $22 \%$ based on latest studies (Missankov et al., 1996 \& Havaldar et al.). The inferior epigastric artery provided aberrant obturator artery ranging from 20 to $34 \%$ (Bergman et al.). In present study, the inferior epigastric artery provided aberrant obturator branch in $0.3 \%$. The aberrant obturator artery arising from the inferior epigastric artery was a known as the corona mortis or crown of death (Roberts and Krishingner, 1967; Jakubowicz \& Czerniawska-Grzesiñska; Tornetta et al., 1996 \& Okcu et al., 2004) this was described based on morphological features (Missankov et al. \& Berberoglu et al.). The incidence of crown of death position of the artery has been estimated between $8 \%$ and $61 \%$ (Missankov et al.; Teague et al., 1996; Tornetta et al.; Gilroy et al., 1997; Berberoglu et al.; Okcu et al., 2004; Drewes et al., 2005; Requarth \& Miller, 2011). In a review study done by Roberts and Krishingner (1968), the highest incidence of variations of the pubic anastomosis was found to be in South black American compared to North American, European and Japanese populations. On the other hand, the inferior epigastric artery arose with the aberrant obturator artery as from common trunk of external iliac artery in 1.3 $\%$ in United Kingdom population (Caucasian) which was more in females than in males in the present study.

Understanding the morphological features of inferior epigastric artery giving obturator or its accessory artery has been linked with the coexistence of sciatic artery (Al Talalwah \& Soames, 2014). Therefore, the presence of vascular variability is due to development or involution of the primitive plexus (Senior, 1925).

\section{CONCLUSION}

The risk of bleeding is high in case of anterior or posterior pelvic fractures due to obturator and aberrant obturator artery (arising from the external iliac or inferior epigastric artery) or persistent sciatic artery injury respectively. The inferior epigastric artery giving the obturator artery and its accessory branch crosses the superior pubic rami to become susceptible to injuries during operation such as hernial repairs, internal fixation of pubic fracture and skin flap transplantation due to close relation of inguinal and femoral rings,. Consequently, the radiologists have to alert surgeon to minimize severe intra-pelvic bleeding due to obturator or its accessory artery injury.

\section{ACKNOWLEDGMENT}

I would like to thank Prof. Roger Soames who permits me to do a research study in Centre for Anatomy and Human Identification (CAHID). In addition, I would like to thank the entire employees of CAHID as well as King Saud bin Abdulaziz University for Health Sciences for providing the essential services.

AL-TALALWAH, W. Arteria epigástrica inferior: estudio anatómico y significancia clínica. Int. J. Morphol., 35(1):7-11, 2017.

RESUMEN: La arteria epigástrica inferior se origina generalmente de la arteria ilíaca externa, pudiendo presentar diferentes orígenes. El objetivo del presente estudio es proporcionar suficiente información de la arteria epigástrica inferior de su importancia para los clínicos, radiólogos, cirujanos, cirujanos ortopédicos, obstetras y ginecólogos. El estudio incluyó 171 cadáveres disecados (92 masculinos y 79 femeninos) pertenecientes a individuos caucásicos de Arabia Saudita con la finalidad de investigar el origen y las ramas de la arteria epigástrica inferior. La arteria epigástrica inferior fue hallada como rama directa independiente de la arteria ilíaca externa en un 83,6\%. La arteria epigástrica inferior se originaba de la arteria iliaca externa en un tronco común con la arteria obturatriz o arteria obturatriz accesoria en el 15,1\% y 1,3\%, respectivamente. La arteria epigástrica inferior daba una rama obturatriz y una obturatriz accesoria en el 3,3\% y 0,3\%, respectivamente. De esta manera, la vascularización retropúbica fue del $20 \%$, siendo mayor en mujeres que en hombres. Como la región retropúbica incluye una elevada variación vascular, esta arteria tiene que ser considerada antes del acto quirúrgico, como en los casos de la cirugía de hernia, la fijación interna en fracturas del pubis y el trasplante de colgajo de piel. Los radiólogos tienen que informar a los médicos tratantes de estas variaciones para contribuir en la disminución de la hemorragia intra-pélvica debido a la lesión iatrogénica de la arteria obturatriz o su arteria accesoria.

PALABRAS CLAVE: Arteria epigástrica inferior; Arteria obturatriz; Arteria obturatriz accesoria; Hernia obturatriz accesoria; Corona Mortis; Fractura de pubis. 


\section{REFERENCES}

Al Talalwah, W. \& Soames, R. Internal iliac artery classification and its clinical significance. Rev. Argent. Anat. Clin., 62:63-71. 2014.

Berberoglu, M.; Uz, A.; Ozmen, M. M.; Bozkurt, M. C.; Erkuran, C.; Taner, S.; Tekin, A. \& Tekdemir, I. Corona mortis: an anatomic study in seven cadavers and an endoscopic study in 28 patients. Surg. Endosc., 15(1):72-5, 2001.

Bergman, R. A.; Thompson, S. A.; Afifi, A. K. \& Saadeh, F. A. Compendium of Human Anatomic Variation: Catalog, Atlas, and World Literature. Baltimore, Urban \& Schwarzenberg, 1988.

Biswas, S.; Bandopadhyay, M.; Adhikari, A.; Kundu, P. \& Roy, R. Variation of origin of obturator artery in Eastern Indian population - A study. J. Anat. Soc. India, 59(2):168-72, 2010.

Bleich, A. T.; Rahn, D. D.; Wieslander, C. K.; Wai, C. Y.; Roshanravan, S. M. \& Corton, M. M. Posterior division of the internal iliac artery: Anatomic variations and clinical applications. Am. J. Obstet. Gynecol., 197(6):658.e1-5, 2007.

Drewes, P. G.; Marinis, S. I; Schaffer, J. I.; Boreham, M. K. \& Corton, M. M. Vascular anatomy over the superior pubic rami in female cadavers. Am. J. Obstet. Gynecol., 193(6):2165-8, 2005.

Gilroy, A. M.; Hermey, D. C.; DiBenedetto, L. M. ; Marks, S. C. Jr.; Page, D. W. \& Lei, Q. F. Variability of the obturator vessels. Clin. Anat., 10(5):328-32, 1997.

Havaldar, P. P.; Taz, S.; Angadi, A. V. \& Saheb, S. H. Morphological study of obturator artery. Int. J. Anat. Res., 2(2):354-7, 2014.

Hussein, M.; Sharma, A. K. R.; Haque, M. \& Usman, N. Variable branching patterns of right and left internal and external iliac arteries and its clinical significance in north indian population. Bull. Pharm Med. Sci., 1(2):101-7, 2013.

Jakubowicz, M. \& Czerniawska-Grzesiñska, M. Variability in origin and topography of the inferior epigastric and obturator arteries. Folia Morphol. (Warsz.), 55(2):121-6, 1996.

Kawai, K.; Honma, S.; Koizumi, M. \& Kodama, K. Inferior epigastric artery arising from the obturator artery as a terminal branch of the internal iliac artery and consideration of its rare occurrence. Ann. Anat., 190(6):541-8, 2008.

Lee, E. Y.; Kim, J. Y.; Kim, H. N.; Sohn, H. J. \& Seo, J. H. Variant origin of obturator artery: A branch of inferior epigastric artery from external iliac artery. Korean J. Phys. Anthropol., 26(3):12530, 2013.

Mahato, N. K. Retro-pubic vascular anomalies: A study of abnormal obturator vessels. Eur. J. Anat., 13(3):121-6, 2009.

Maneesha, S.; Tripta, S.; Richhpal, S. \& Kaur, A. A. Variations of obturator artery in man. Anat. Physiol., 2(3):1000105, 2012.

Missankov, A. A.; Asvat, R. \& Maoba, K. I. Variations of the pubic vascular anastomoses in black South Africans. Acta Anat. (Basel), 155(3):212-4, 1996.

Pai, M. M.; Krishnamurthy, A.; Prabhu, L. V.; Pai, M. V.; Kumar, S. A. \& Hadimani, G. A. Variability in the origin of the obturator artery. Clinics (Sao Paulo), 64(9):897-901, 2009.

Requarth, J. A. \& Miller, P. R. Aberrant obturator artery is a common arterial variant that may be a source of unidentified hemorrhage in pelvic fracture patients. J. Trauma, 70(2):366-72, 2011.

Rusu, M. C.; Cergan, R.; Dermengiu, D.; Curca, G. C.; Folescu, R.; Motoc, A. G. \& Jianu, A. M. The iliolumbar artery-anatomic considerations and details on the common iliac artery trifurcation. Clin. Anat., 23(1):93-100, 2010.

Sakthivelavan, S.; Aristotle, S.; Sendiladibban, S. D. \& Jebakkani, C. F. Variability of the obturator artery and its surgical implications in a South Indian population. Eur. J. Anat., 17(3):159-65, 2013.

Sañudo, J. R.; Mirapeix, R.; Rodriguez-Niedenführ, M.; Maranillo, E.; Parkin, I. G. \& Vázquez, T. Obturator artery revisited. Int. Urogynecol. J., 22(10):1313-8, 2011.
Sarikcioglu, L.; Sindel, M.; Akyildiz, F. \& Gur, S. Anastomotic vessels in the retropubic region: corona mortis. Folia Morphol. (Warsz.), 62(3): 179-82, 2003.

Standring, S. Gray's Anatomy. The Anatomical Basis of Clinical Practice. 39th ed. New York, Elsevier Churchill Livingstone, 2005.

Senior, H. D. An interpretation of the recorded arterial anomalies of the human pelvis and thigh. Am. J. Anat., 36(1):1-46, 1925.

Teague, D. C.; Graney, D. O. \& Routt, M. L. Jr. Retropubic vascular hazards of the ilioinguinal exposure: a cadaveric and clinical study. J. Orthop. Trauma, 10(3):156-9, 1996.

Tornetta, P. 3rd.; Hochwald, N. \& Levine, R. Corona mortis. Incidence and location. Clin. Orthop. Relat. Res., (329):97-101, 1996.

Corresponding author:

Dr. Waseem Al Talalwah

King Saud bin Abdulaziz University for Health Sciences, Riyadh

Department of Basic Medical Sciences

College of Medicine

PO Box 3660, Riyadh 11481

Mail Code: 3127

KINGDOM OF SAUDI ARABIA

Email: altalalwahw@ksau-hs.edu.sa

Received: 19-05-2016

Accepted: 24-11-2016 